\title{
Evolution or regress of the size and scope of global phenomenon of money laundering
}

\author{
Akad AL-KASAWNIH \\ Bucharest University of Economic Studies, Bucharest, Romania \\ akad.khasawneh@fm.gov.jo.
}

\begin{abstract}
The challenges facing an international economy in which the importance of the tertiary and quaternary sectors greatly increases, sometimes to the detriment of the primary and secondary ones, in which the financial flows far outstrip the real economic ones and in which the picture of the market participants is changed radically, they are increasingly numerous, more complex and require another type of mechanism to meet them. An almost organic companion of the processes of liberalization of the crossborder economic and financial flows and of the deregulation required by the alignment with the dominant economic philosophy, the non-functionalist one, has been the phenomenon of proliferation of tax havens towards which more and more financial assets flows for decades. These developments are concomitant with the deepening of income inequalities, between states but also within them, with the amplification of the acute lack of resources which can deal with some of the effects of worrying climate developments, with the placing of analysts in the academic environment but also of the political decision makers. of the subject entitled "just transition". The amplification of the financial transactions carried out through these areas of derogatory taxation, has led to the accumulation of great dissatisfaction among several segments of the company that demand the reform of the economic governance mechanisms so that one can hope to correct the blatant malfunctions and to bring to light and bring to light under the control of civil society of societal deviant behavior from public morality and economic rationality. As a result of scandals of great media relevance, there has been an increasing tendency in international society to take measures, both nationally and internationally, which will help reduce the money-laundering phenomenon. The author intends to analyze the effectiveness with which a series has been implemented and regulations meant to place under a stricter control the evolution of the money laundering phenomenon. The emphasis is on the particularities of money laundering through the Internet and Electronic Commerce because using such a mechanism through the use of electronic financial transfer, the huge growth in the size and speed of financial flows can reduce the chances of detecting the movement of illegal funds.
\end{abstract}

Keywords: globalization, underground activities, money-laundering, three F`s, methods to hide the origin of dirty money.

\section{Introduction}

As we are told from the headquarters of the International Monetary Fund, the global economy is confronted with many challenges the most pressing of them being tensions on the trade front, fiscal and financial risk, and the ongoing struggle to attain inclusive growth. Experts recommend that both public policy makers and researchers in the field of international economics focus more on sensitive issues such as: the slowdown in productivity growth; income polarization; low inflation and low levels of wage growth and the continuing need for global cooperation. Of all these, the area in which quite a bit has been done lately but much more needs to be done, especially in the current rather tense circumstances, is that of international cooperation. It has become more important than ever for government decision-makers to urgently identify and address issues that create unexpected, negative spillovers, increase tensions between countries or erode the incentives for economic integration. The elements that define the current international economic picture are: the importance of the tertiary and quaternary sectors greatly increases, sometimes to the detriment 
of the primary and secondary ones; the financial flows far outstrip the real economic ones; the picture of the market participants is changed radically, they are increasingly numerous, more complex and require another type of mechanism to meet them; the amplification of the financial transactions carried out through the areas of derogatory taxation, has led to the accumulation of great dissatisfaction among several segments of the society that demand the reform of the economic governance mechanisms. Is there more pressing the demand to correct the blatant malfunctions and to bring to light under the control of civil society of societal deviant behavior from public morality and economic rationality

The economic manifestations of globalization are the most obvious, most complete and onthe-ground, and include a rapid integration of functions between geographically dispersed sectors and economic activities. The economic globalization is the era of the profound capitalist transformation of all mankind under the domination, leadership and control of the countries of the Center under the rule of a global economic system of unequal exchange. During this scientific paper the author set out to find the most reasoned answers to a series of questions such as: In how many sectors is a national economy currently structured? How different were the means by which economic actors can adapt to the new stage of globalization? Has the liberalization of economic flows achieved the goals envisaged by its supporters? Under the new international economic landscape, has the phenomenon of money laundering become more acceptable? Have we witnessed in recent years the extension of the money laundering phenomenon to the economies in transition and the developing ones? Why there is no clear desire of decision makers in developed countries to reduce or eliminate the phenomenon of money laundering? How economic globalization mechanisms contribute to facilitate the crime of money laundering taking in consideration the complex nature of overlapping between the mechanisms of both?

The main hypothesis of the paper was that the greater the cross-border financial flows, the greater the money-laundering operations and negative impact on the behavior of the economic actors. What distinguishes this study is Quantitative and analytical analysis, through the adoption of a digital index for economic globalization and the adoption of another numerical indicator for money laundering. Additionally, a statistical analysis of the relationship between economic globalization and money laundering will be based on "Pearson correlation coefficient" as we are going to adopt one independent variable (Economic Globalization- as an indicator for cross-border financial flows) and another dependent variable (Money Laundering- as an indicator for money laundering). The KOF index of globalization adopted in this study as it covers most of the world countries (178 countries in 2018). Study samples were taken from various countries of the world. These countries have been divided into three groups (Group 1: Countries with high economic globalization; Group 2: Countries with a moderate economic globalization; Group 3: Countries with low economic globalization), each category of them includes five countries from different parts of the world. The selected countries given a ranking from 1 to 15 according to their degree of economic globalization. This study will induce the volume of money laundering through the hidden economy or the shadow economy. The study refers to most recent studies that tried to induce the volume of money laundering through the hidden economy which is presented by Leandro Medina and Friedrich Schneider that is published in 2018. The results are covering 158 countries all over the world and it were presented over 1991 to 2015.

Despite growing concerns at national and international level, the phenomenon of money laundering still remains at very high levels 
There is a deep debate at these times about the effects of open borders, trade liberalization, free flow of capital and privatization on world jobs and wages and the prosperity of nation-states. Where some blame these phenomena as one of the pillars of economic globalization by achieving huge losses in jobs and wages, others emphasize the effects of "luxury" that have contributed to. However, few interlocutors address the effects of globalization on the emergence of criminal organizations, the growing trade in illicit weapons, drugs, prostitution and stolen antiquities by exploiting the opportunities offered by globalization. Despite the improvement of the ways of identifying the forms and quantifying the extent of this phenomenon, the estimates remain debatable Regardless of the method of quantification used, we can say that the approximate magnitude of this scourge is around the level of $2-5 \%$ of global GDP, or $\$ 800$ billion - \$ 2 trillion in current US dollars. A specialized body (United Nations Office on Drugs and Crime) (UNODC, 2011) has drafted a cape document on the size, narrowness and entrainment of money laundering. One of the most valuable idea that can be deduced from this document is that ,once illegal money has entered the global and financial markets, it becomes much harder to trace its origins, and the laundering of ill-gotten gains may perpetuate a cycle of crime and drug trafficking,.. According to latest statistics from the Europol and other authorities there is a significant increasing amount of money laundering volume of transactions that can arrive to $2-5 \%$ of GDP, even if this number is an estimate as it is very difficult to get an exact number of any illegal activity. There are serious threats coming from international operations of money laundering pertaining the effect of globalization. It should be noted that money laundering is mainly and foremost an economic issue. The nature of this kind of activities start from local, to national and in most of the cases becomes transnational and international in full maturity of the organizations. (Arnone, M., \& Borlini, L. 2010). One of the ways states deal and should deal with this, is closely related to increasing the costs of the activities, which asks for legal and enforcement support. Increased legal support and enforcement means also higher costs and generally a concern for privacy violation. These are typical trade-offs that every state should carefully consider and study. Under normal and observed experience, increased regulation enforcing law activities help to discover and punish the laundering activities.

Statistical data shows a worrying escalation of the fiscal evasion due to the important gains they generate. It is becoming increasingly obvious that the phenomenon of money laundering has spread even as the world's global financial infrastructure is connected to the global financial infrastructure: banks, brokerage houses, stock exchanges, investment funds and other financial institutions of the world's economic mechanisms. Specialists believe that among the factors that contributed to the proliferation of this scourge we find the process of economic globalization and the development of global financial infrastructure. To these can be added: new opportunities for rapid transfer of people and capital along state borders; Well-developed forms of organized criminal groups; High profitability of criminal activities. Regardless of the forms in which this phenomenon manifests itself, and of the tricks that our practitioners use, we can say that its operational principles are essentially the same.

Deepening of the process of deregulation in the case of almost all economic flows, fast and ever-changing technological improvements, as well as ease of communication have all become a helping hand and a booster of illegal cross-border activities. One other factor that helps the illegal processes is the legal procedures and laws' difference that enables money laundering companies to take advantage of the asymmetries in information and legislation between countries. The nature of these outlaw activities is economic, and these activities are very profitable. A complete suppression of those infractions, along with other activities like; tracing, blocking and confiscation of the 
financial resources or assets should be applied to illuminate such illegal activities. Money laundering sensitivity is of a nature that not only the illegal and outlaw activities, but also the dirty money that enters the system legally, that too should be checked and appropriately dealt with when there are enough reasons to doubt the transactions. These procedures that are designed to prevent and to discover such activities, like the KYC (Know your client) procedures aimed at professionals and institutions that mostly interact with companies or individuals that can be subject to money laundering. Money laundering can have significant, measurable harmful economic effects. This can play a crucial role in polices designed to address criminal financial activity. Money laundering is the basic activity that permits criminal organizations to resist and profit in their criminal activities. Socially there are consequences that relate to the economic influence of illicit organizations, which enables them to subvert the legal economy, to entice people in charge and people of power so that to have an adapt environment for the activity. Laundering of money can have various economic, social, and political outcomes. Direct effects are those that are related to the crimes directly to persons, organizations or to society. As some authors mentioned (Borlini, L. 2008) while many other effects of money laundering are indirect and not directly related to the case. Even though the laws of anti-money laundering are passed and applied, there is evidence that shows the overflow of useless anti-money-laundering information like in the U.S. case (Pieth \& Aiolfi, 2004) and in United Kingdom (Gold \& Levi, 1994) There are also some general conclusions coming from studies that the affectivity of those laws and legislation even though positive remains low (Naylor, 2002).

At first there is an amount of money coming directly from the illegal sources that is placed in a financial institution or used to buy an asset, and this is called the assignment, placement or in jargon called the prewash. This step is where the money is delivered. There are some practices like arranging great amounts into smaller sums for deposits or investment and to divide the whole into tiny undetectable pieces that can evade the system and go undetected. The second step is layering, efforts are made to conceal the real source of the funds and assets. This can be made by techniques like moving money around the world in order to hide its origins. There are many ways to do this, some of those include: banking in correspondence or global payment online systems that don't use intermediary banks, just a central or two central banks, checks, collective accounts, loans at low or no interest at all, fake invoices, false insurances, made-up sales and purchases and of course the using shell companies. In this stage it comes the role of the dirty money where it is finally ready to penetrate the financial system as a solid and legitimate money source. (Ross, S., \& Hannan, M. 2019). Sometimes, the three processes are visible and distinguishable, but they can also happen at nearly the same time or even overlap. One thing that is almost always needed an organizer, a banker or similar person involved and employed in a large financial institution that can be a lawyer, banker or similar. Some of the subjects are more likely to have more resources available or more possibilities to apply such schemes, these institutions are those that can have large sums of money available like deposit institutions as banks, non-bank financial institutions, or non-financial institutions. Money launderers have the necessity to get out of cash; the deposit accepting organizations are used firstly. This raised the sensibility and procedures designed in the banks to identify and report susceptible actions. The bank staff and its integrity is crucial in this process, and this is why the staff of banks is trained continuously and 'bribe-proofed' with cameras and other control processes. (Reuter, P., \& Truman, E. M. 2004).

Another important vehicle used for completing laundering operations are nonfinancial business of various types. These organizations are vulnerable to money laundering and crime originating finances. Their focus is on hiding the true beneficiaries, which is also the key reason. 
In these cases, the businesses are legitimate, but they interact very closely with shell-companies, or are owned or are financed by them. The funding which comes from the shell companies is the money to be laundered with the legitimate business as vehicle, and a tool for entering the money in the system. In some cases, this dirty money is used for funding, establishing and investments in the new businesses opened and owned by those shell companies. Shell companies' owners are never disclosed, and the real owners remain hidden for all the lifetime of the business. The corporations and businesses diverge in type, dimension, industry etc. they can be corporate, retail shops, car washes, enterprises, restaurants, and other business in hospitality. At this stage, after the business is active and operating then funds can enter the system and combine with real clean money from the business, leaving no loose ends and laundering the money that was founded. Experience shows that businesses like shell companies are established in offshore financial centers that can help with the laundering process in scale. That companies in offshore 'heavens' are very effective mostly in the first two steps of the process, in assignment and layering. There are some industries in which businesses deal with large amounts of cash like casinos, luxury goods market, gambling companies. Those high cash managing businesses are very lucrative and enticing to the money launderers. Another type of company that is vulnerable to be penetrated by money launderers are the non-profit organizations around the globe. The legal and free professionals can often be very much in the position to come in contact first with these types of organizations and are the first line of defense against organized financial crime. These professionals like lawyers and accountants have done a lot in the past and are referring to improved laws like the KYC (Know Your Client) procedures that help them reveal possible susceptible operations and revert those cases to the appropriate law enforcing institutions.

\section{How relevant are the tools used to measure the extent of the money laundering phenomenon?}

Both academics and corporate specialists and public policy makers have long concluded that there is a tax evasion that can be classified as illegal but also one that is considered lawful. Based on literature review we can say that the range of factors that favor tax evasion is wider and wider. Illicit tax evasion has a variety of forms, the most widespread being: traditional evasion; legal evasion; accounting evasion; evasion through evaluation. The main issues underlying illicit tax evasion are: evasion of taxes by incorrect recording of economic transactions in the accounting data; operation of so-called phantom companies; destruction of financial and accounting documents; the organization of double accounting records; drawing up accounting balances based on unrealistic data; not declaring commercial activities or sources of taxation; the subsistence of some economic activities without the declaration of subsidiaries, working places and entrepreneurship; the submission of false documents on import-export operations. The factors that favor licit tax evasion are: granting tax incentives in the form of exemptions, partial exemptions, reductions, deductions; granting temporary delimitation exemptions in the event of the establishment of new companies; removing from the tax the income from bank deposits and from investments in government bonds; the non-regulation of the general expenses of the companies, which creates the temptation of the overvaluation through their unjustified economic growth; the taxation of income from certain categories of natural persons, on the basis of average working standards, creates conditions for taxpayers who earn higher than the average not to pay taxes for that difference; exploiting some gaps in the law.

There are several ways of estimating the size of money laundering by estimating the size of the hidden economy, which includes the proceeds of illicit activities, which are all revenuegenerating activities not recorded in GNP accounts, either to hide it from the legal obligations 
associated with the disclosure of such activities, or because such activities, by their very nature, are activities contrary to the prevailing legal system in the country. One can opt for direct methods of quantifying the phenomena of tax evasion and money laundering focusing on well-designed surveys or samples based on voluntary replies, or tax auditing and other compliance methods. Sample surveys designed to estimate the shadow economy are widely used. It is based on the estimation of the volume of activities in the hidden economy. The partial values of these activities are then aggregated to obtain an estimate of the size of the hidden economy at the level of the countries as a whole. The main disadvantages of this method are the flaws inherent in all surveys. For example, the average precision and results depend greatly on the respondent's willingness to cooperate, it is difficult to assess the amount of undeclared work from a direct questionnaire, most interviewees hesitate to confess to fraudulent behavior, and responses are of uncertain reliability, which makes it difficult to calculate a true estimate (in monetary terms) of the extent of undeclared work. The main advantage of this method lies in the detailed information which can be obtained about the structure of the shadow economy, but results from these kinds of surveys are very sensitive to the way the questionnaire is formulated. (Schneider, F. Buehn, A. 2016) This method is used either in structured survey or selected samples. It is usually difficult for those who implement this method to limit all activities of the hidden economy. Therefore, the size of the estimated hidden economy may differ substantially from its real size. Some countries resort to this method, such as the United States of America.

Most of the time, experts use indirect methods to estimate the amplitude of these phenomena. Approaches which are also called indicator approaches, are mostly macroeconomic and use various economic and other indicators that contain information about the development of the shadow economy over time. Relating them to the definition of the shadow economy, they provide value added figures. In most cases, legally-bought material is often included; hence, they provide upper-bound estimates with the danger of a double counting problem due to the inclusion of the legally-bought material. Therefore, a wide (broad) definition of the shadow economy is applied; especially as some criminal activities like human trafficking are also included. The most frequently used model with the help of trying to capture the various facets of this provocative phenomenon is Walker Gravity Model. The model shows that it is possible to produce more accurate figures using a simple model of economic crime based on a global database, based on information about global trends in the field of Crime and Money Laundering. To increase the accuracy of the results obtained by using this econometric architecture one need to prove that these data can be compiled to produce a model that measures the size of money laundering in the world, trying to estimate the amount and proceeds of crime and the laundering potential, and addresses the question of the proportion of funds likely to be washed within the same country or sent to another country, and the destination that will receive the funds, in addition to estimating the total flows from and to each country to provide a global total aggregate. In this paper, the author proceeded to perform a statistical analysis conducted to examine the relationship between economic globalization and money laundering that will be based on "Pearson Correlation Coefficients" haven in mind that this correlation coefficient is one of the most common methods for measuring the appropriate correlation between two variables. I have adopted the economic globalization variable as an independent variable and money laundering variable as a dependent variable. This statistical indicator is relevant only where the correlation coefficient value is always between -1 and 1. For example: If the correlation coefficient value is positive, the correlation is positive, which means increasing the value of the independent variable will increase the value of the dependent variable. And if the correlation coefficient value is negative, the correlation is 
inverse, which means the increase of the value for the independent variable leads to the decline of the value for the dependent variable. Furthermore, the correlation is very strong when the value is close to 1 or -1 , and when the value approaches somehow to "zero" that means a weak relationship or correlation between the variables, and if the value is "zero" so there is no correlation between the two variables at all. The analysis methodology will be as follows:

a) Economic Globalization (Independent Variable). The author used the KOF index of globalization, and the selected countries as a study samples will be given a ranking from 1 to 15 according to their degree of economic globalization. The most globalized country (Singapore) is 15 while the least globalized (Bangladesh) is 1.

Table. 1. The ranking of the selected countries according to the KOF scale of overall economic globalization:

\begin{tabular}{|c|c|c|}
\hline Country & Overall Economic Globalization & Ranking \\
\hline Switzerland & 91.19 & 15 \\
\hline United States & 82.41 & 14 \\
\hline Romania & 79.74 & 13 \\
\hline Jordan & 73.99 & 12 \\
\hline Nicaragua & 64.74 & 11 \\
\hline Thailand & 59.89 & 9 \\
\hline Guatemala & 54.76 & 8 \\
\hline Saudi Arabia & 53.03 & 7 \\
\hline Russian Federation & 50.95 & 6 \\
\hline Tunisia & 46.08 & 5 \\
\hline Indonesia & 44.23 & 4 \\
\hline Egypt & 34.50 & 3 \\
\hline India & 29.78 & 2 \\
\hline Bangladesh & 20.95 & 1 \\
\hline
\end{tabular}

Source: Authors estimations based on the KOF Index of Globalization Gygli, Savina, Florian Haelg, Niklas Potrafke and Jan-Egbert Sturm (2019)

b) Money Laundering (Dependent Variable). The size of the hidden economy will be adopted here. But we should notify that "hidden economy" means all revenue-generating activities that not recorded in GDP; Either to hide it or to evade the legal obligations associated with the disclosure of such activities, or because the nature of such activities are against the legal system in the country. According to this definition, the activities of the hidden economy 
include all incomes generated in legitimate way but not disclosed to tax administrations, as well as traditional criminal activities such as drug trafficking, gambling, smuggling and others. The selected countries as a study samples will be given a ranking from 1 to 15 according to the average size of the hidden economy between 2004 and 2015. The largest size of the hidden economy within the study sample goes for (Guatemala) that will be given 15 and the lowest size for (United States) that will have number 1.

Table. 2. The ranking of the selected countries according to the average size of the hidden economy between 2004 and 2015:

\begin{tabular}{|c|c|c|}
\hline Country & $\begin{array}{c}\text { Average Size of the Hidden } \\
\text { Economy }\end{array}$ & Ranking \\
\hline Guatemala & 54.74 & 15 \\
\hline Thailand & 50.63 & 14 \\
\hline Nicaragua & 42.63 & 13 \\
\hline Switzerland & 40.04 & 12 \\
\hline Russian Federation & 38.42 & 11 \\
\hline Tunisia & 35.31 & 10 \\
\hline Egypt & 34.24 & 9 \\
\hline Bangladesh & 33.24 & 8 \\
\hline Romania & 30.14 & 7 \\
\hline Indonesia & 24.11 & 6 \\
\hline India & 23.91 & 5 \\
\hline Jordan & 17.38 & 4 \\
\hline Saudi Arabia & 16.65 & 3 \\
\hline Singapore & 11.90 & 2 \\
\hline United States & 8.34 & 1 \\
\hline
\end{tabular}

Source: World Bank WDI 2017

In order to obtain more accurate results, a number of sub-indices in the actual economic flows of the economic globalization index (de facto) will be taken as an independent variable to study the relationship between economic globalization and money laundering. The following tables show the ranking of the sample countries based on these sub-indicators, which include: trade globalization (trade in goods, trade in services, trade partner diversification), and financial 
globalization (foreign direct investment, portfolio investment, international debt, international income payments) all of them in relation to the percentage of GDP, and then the overall economic globalization index will be used as an independent variable to interpret the relationship as a whole.

Table. 3. The ranking of the selected Countries according to overall economic globalization and its sub-indicators:

\begin{tabular}{|c|c|c|c|c|c|c|c|c|c|c|}
\hline \multirow{2}{*}{$\begin{array}{c}\text { Country } \\
\text { Guatemala }\end{array}$} & \multicolumn{2}{|c|}{$\begin{array}{c}\text { International } \\
\text { Trade in } \\
\text { Goods and } \\
\text { Services* }\end{array}$} & \multicolumn{2}{|c|}{$\begin{array}{l}\text { Foreign Direct } \\
\text { Investment** }\end{array}$} & \multicolumn{2}{|c|}{$\begin{array}{c}\text { portfolio } \\
\text { investment }^{* * *}\end{array}$} & \multicolumn{2}{|c|}{$\begin{array}{c}\text { Overall } \\
\text { Economic } \\
\text { Globalization }\end{array}$} & \multicolumn{2}{|c|}{$\begin{array}{c}\text { Average } \\
\text { Size of the } \\
\text { Hidden } \\
\text { Economy }\end{array}$} \\
\hline & 6.3 & 1 & 980.62 & 5 & 447.90 & 3 & 54.76 & 8 & 54.74 & 15 \\
\hline Thailand & 11.3 & 6 & $116,526.94$ & 10 & $53,422.80$ & 10 & 59.89 & 9 & 50.63 & 14 \\
\hline Nicaragua & 15.9 & 11 & 640.60 & 3 & 203.60 & 2 & 64.74 & 11 & 42.63 & 13 \\
\hline Switzerland & 7.5 & 4 & $1,700,827.09$ & 14 & $1,410,330.66$ & 14 & 83.82 & 14 & 40.04 & 12 \\
\hline $\begin{array}{c}\text { Russian } \\
\text { Federation }\end{array}$ & 12.1 & 7 & $468,567.46$ & 12 & $73,945.51$ & 11 & 50.95 & 6 & 38.42 & 11 \\
\hline Tunisia & 16 & 12 & 502.36 & 1 & 50.72 & 1 & 46.08 & 5 & 35.31 & 10 \\
\hline Egypt & 15.7 & 10 & $7,426.00$ & 6 & $1,556.50$ & 5 & 34.50 & 3 & 34.24 & 9 \\
\hline Bangladesh & 25.2 & 15 & 797.06 & 4 & $3,193.96$ & 7 & 20.95 & 1 & 33.24 & 8 \\
\hline Romania & 17 & 13 & $8,055.76$ & 7 & $4,528.33$ & 8 & 71.68 & 13 & 30.14 & 7 \\
\hline Indonesia & 12.5 & 8 & $77,189.89$ & 8 & $17,315.66$ & 9 & 44.23 & 4 & 24.11 & 6 \\
\hline India & 21.9 & 14 & $155,175.73$ & 11 & $2,565.33$ & 6 & 29.78 & 2 & 23.91 & 5 \\
\hline Jordan & 6.5 & 2 & 619.01 & 2 & 666.06 & 4 & 68.15 & 12 & 17.38 & 4 \\
\hline Saudi Arabia & 10.9 & 5 & $79,069.55$ & 9 & $156,976.41$ & 12 & 53.03 & 7 & 16.65 & 3 \\
\hline Singapore & 13.3 & 9 & $841,402.36$ & 13 & $1,248,931.02$ & 13 & 92.47 & 15 & 11.90 & 2 \\
\hline United States & 7.2 & 3 & $8,909,995.00$ & 15 & $12,543,844.00$ & 15 & 63.83 & 10 & 8.34 & 1 \\
\hline
\end{tabular}

Source: *World Bank WDI 2017.(http://wdi.worldbank.org/table/4.9)/ (Sum of average annual growth for exports and imports in goods and services as share of GDP). **: International Monitory Funds (IMF) 2017. (http://data.imf.org/regular.aspx?key=61468209) ***: International Monitory Funds (IMF) 2017. (http://data.imf.org/regular.aspx?key=61468209).

The dependent variable of the size of the hidden economy in this study will follow the change in each of the sub-indices in the actual economic flows of economic globalization. To measure this, the above scores will be analyzed according to the "Pearson Correlation Coefficient" 
to produce results showing the correlation between the two variables.After performing the statistical analysis according to the above data, Pearson Correlation Coefficient is as follows:

- The relationship between the ratio of international trade to GDP and the hidden economy that represents the volume of money laundering: Pearson Correlation Coefficient was $(0.0152+)$, which means that there is a positive weak relationshipcorrelation between the ratio of international trade to the gross national product of the state and money laundering phenomenon represented by the size of the hidden economy.

- The correlation between the ratio of foreign direct investment to gross domestic product (GDP) and the hidden economy, which represents the volume of money laundering: Pearson Correlation Coefficient was $(0.4989+)$, which means that there is a positive medium relationship correlation between the ratio of foreign direct investment to the gross domestic product (GDP) of the state and the phenomenon of money laundering which represent the size of hidden economy.

- The relationship between the ratio of portfolio investment to GDP and the hidden economy, which represents the volume of money laundering: Pearson Correlation Coefficient was (0.3751-), which means that there is a negative weak relationship correlation between the ratio of portfolio investment to the gross domestic product and the phenomenon of money laundering which represent the size of hidden economy.

- The relationship between the overall economic globalization and the average size of the hidden economy, which represents the volume of money laundering: After the statistical analysis according to the data referred to above, Correlation Coefficient Pearson has reached (0.1533-), which means that there is a negative weak relationship correlation between the degree of the economic globalization of the state and the phenomenon of money laundering which is represented by the size of the hidden economy.

One of the hypotheses of this study is that there is a causal relationship between economic globalization (independent variable) and money laundering operations (dependent variable), and the direction of this relationship is a positive relationship, as we noticed earlier there is a positive weak relationship between the sub-indices of economic globalization and money laundering when we take some of the indices (international trade $0.0152+$, foreign direct investment $0.4989+$ ). While there is a negative weak relationship when it is applied on other indices (portfolio investment to GDP 0.3751-).As a result, the overall index of economic globalization and the total average size of the hidden economy will be adopted to measure the relationship between these two variables by using the Pearson Correlation Coefficient that was (0.1533-), which means that there is a negative weak relationship correlation between the degree of the economic globalization of the state and the phenomenon of money laundering which is represented by the size of the hidden economy. One of the hypotheses of this study is that there is a causal relationship between economic globalization (independent variable) and money laundering operations (the dependent variable), and the direction of this relationship is a positive, while the result of these study shows the opposite (a negative weak relationship correlation between the degree of the economic globalization of the state and the phenomenon of money laundering which is represented by the size of the hidden economy) which means that the increase of the value for the independent variable (economic globalization) leads to the decline of the value for the dependent variable (money laundering). The negative correlation coefficient value can be explained to more than one reason due to the following:

The effectiveness of the international efforts to combat money laundering, whether by the country itself or in cooperation under the umbrella of many international institutions and bodies 
that deal with combating financial and economic crimes, mainly money laundering, as these efforts are more effective in developed industrial countries.

The difficulty of having accurate measurement for the volume of money laundering in the countries of the world, as all international institutions concerned with the fight against money laundering refrain from providing estimates on the real size of this phenomenon and only provides estimations. Therefore, this is replaced by the measurement of indicators of the size of money laundering, as we did in this study where the size of the hidden economy was used.

The phenomenon of money laundering is linked to the origins of these funds, which have their own dimensions (economic, social, political and geographic ones). Therefore, the effects cannot be limited to economic and financial forms of globalization only.

\section{Concluding remarks}

The relationship between the overall economic globalization which represent Cross-Borders Flows and the overall average size of hidden economy which represents the volume of money laundering: After the statistical analysis according to the data referred to above using "Correlation Coefficient Pearson" has reached (0.1533-), which means that there is a negative weak relationship correlation between the degree of the economic globalization of the state and the phenomenon of money laundering which is represented by the size of the hidden economy.

Even if the main hypotheses was that there is a causal relationship between economic globalization (independent variable) and money laundering operations (the dependent variable), and the direction of this relationship is a positive, the result of this study shows the opposite (a negative weak relationship correlation between the degree of the economic globalization of the state and the phenomenon of money laundering which is represented by the size of the hidden economy) which means that the increase of the value for the independent variable (economic globalization) leads to the decline of the value for the dependent variable (money laundering).

The effectiveness of the international efforts to combat money laundering, whether by the country itself or in cooperation under the umbrella of many international institutions and bodies that deal with combating financial and economic crimes, mainly money laundering, as these efforts are more effective in developed industrial countries.

The difficulty of having accurate measurement for the volume of money laundering in the countries of the world, as all international institutions concerned with the fight against money laundering refrain from providing estimates on the real size of this phenomenon and only provides estimations. Therefore, this is replaced by the measurement of indicators of the size of money laundering as this study accomplished where the volume of the hidden economy was used.

The phenomenon of money laundering is linked to the origins of these funds, which have their own dimensions (economic, social, political and geographic ones). Therefore, the effects cannot be limited to economic and financial forms of globalization only.

Results of this study shows that a negative weak relationship correlation between the degree of the economic globalization of the state that represent cross-border financial flows and the phenomenon of money laundering that represent the volume of hidden economy, which means that the increase of the value for the independent variable (economic globalization) leads to the decline of the value for the dependent variable (money laundering).

\section{References}


Arnone, M., \& Borlini, L. (2010). International anti-money laundering programs: Empirical assessment and issues of criminal regulation. Journal of Anti-Money Laundering Control, vol. 13 ( no. 2), pp. 226-271.

Borlini, L. (2008). Money laundering conduct in the context of economic globalisation: Economic effects and issues of international criminal regulation. Diritto del Commercio Internazionale, vol. 22 (no. 1), pp. 37-110.

Gold, M., \& Levi, M. (1994). Money laundering in UK: An appraisal of suspicious - based reporting. London, England: Police Foundation.

Naylor, R. T. (2002). Wages of crime: Black markets, illegal finance and the underworld economy. Ithaca, NY: Cornell University Press.

Pieth, M. (2014). International standards against money laundering. In M. Pieth, ed. \& G. Aiolfi (Eds.), A comparative guide to anti-money laundering: A critical analysis of systems in Singapore, Switzerland, the UK and the USA: Cheltenham, England: Edward Elgar. Reuter, P., \& Truman, E. M. (2004). Chasing dirty money: The fight against money laundering. Washington, DC: Institute for International Economics.

Ross, S., \& Hannan, M. (2019). Money laundering regulation and risk-based decision making. Journal of Money Laundering Control, vol. 10 (no. 1), pp. 106-115.

Schneider, F. Buehn; A - Estimating the Size of the Shadow Economy: Methods, Problems and Open Questions, Discussion Paper No. 9820, March 2016, P 9.

*** - Estimating illicit financial flows resulting from drug trafficking and other

transnational organized crimes. Research Report. UNODC, 2011. 